\title{
The Differences Level of Resistin between Positive and Negative Helicobacter pylori Gastritis and its Correlation with Nutritional Status
}

\author{
Widya Deli Satuti*, Gontar Alamsyah Siregar**, Dharma Lindarto**, Imelda Rey** \\ *Department of Internal Medicine, Faculty of Medicine, Universitas Sumatera Utara, Medan \\ ${ }^{* *}$ Division of Gastroentero-hepatology, Department of Internal Medicine, Faculty of Medicine, \\ Universitas Sumatera Utara, Medan \\ ***Division of Metabolic and Endocrinology, Department of Internal Medicine, \\ Faculty of Medicine, Universitas Sumatera Utara, Medan
}

\section{Corresponding author:}

Gontar Alamsyah Siregar. Division of gastroentero-hepatology, Department of Internal Medicine, Adam Malik General Hospital. Jl. Bunga Lau No. 17 Medan Indonesia. Phone/facsimile: +62-61-8365742. Email: gontarsiregar@gmail.com.

\begin{abstract}
Background: H. pylori gastritis can be related to people with obesity and metabolic syndrome. The mechanism underlying the relationship between them is suspected to be caused by adipocytokine called resistin. Objective: to analyze the difference level of resistin between positive and negative H. pylori gastritis patients and their relationship with nutritional status.

Method: This cross sectional study was done in the Gastroenterology department of General Hospital Adam Malik, Medan, from May to October 2019. Patients with gastritis diagnosed by endoscopy underwent rapid urease test (RUT), resistin, albumin, hemoglobin tests, also body mass index (BMI) and waist circumference (WC) were measured.

Results: Sixty gastritis patients found by endoscopic examination, 29 (48.33\%) was H. pylori positive and 31 (51.67\%) was negative. No significant differences were found between BMI, WC, and albumin against $H$. pylori gastritis with $p$ values $0.099,0.055$, and 0.528, respectively. Hemoglobin was found significant with a $p$ 0.009 . The mean resistin in the positive H. pylori group was $7.62 \mathrm{ng} / \mathrm{mL}$ while the negative was $3.23 \mathrm{ng} / \mathrm{mL}$, and statistically significant $(p<0.001)$. There was a strong positive correlation between resistin levels with BMI and WC (BMI p 0.01, r 0.577; WC p 0.001, r 0.592).

Conclusion: Resistin levels in gastritis with $H$. pylori positive are higher than $H$. pylori negative, body mass index and waist circumference have a strong relationship with resistin levels in patients with positive H. pylori gastritis, hemoglobin is lower in H. pylori positive than negative gastritis.
\end{abstract}

Keywords: resistin, gastritis, Helicobacter pylori, body mass index, obesity

\section{ABSTRAK}

Latar belakang: Gastritis H. pylori dapat dikaitkan dengan orang dengan obesitas dan sindrom metabolik. Mekanisme yang mendasari hubungan di antara mereka diduga disebabkan oleh adipositokin yang disebut resistin. Tujuan: untuk menganalisis perbedaan tingkat resistin antara pasien gastritis $H$. pylori positif dan negatif dan hubungannya dengan status gizi. 
Metode: Penelitian cross sectional yang dilakukan di departemen Gastroenterologi Rumah Sakit Umum Adam Malik, Medan, dari Mei hingga Oktober 2019. Pasien dengan gastritis yang didiagnosis dengan endoskopi menjalani pemeriksaan rapid urease test (RUT), resistin, albumin, hemoglobin, serta pengukuran indeks massa tubuh (IMT) dan lingkar pinggang (LP).

Hasil: Enam puluh pasien gastritis ditemukan dengan pemeriksaan endoskopi, 29 (48.33\%) adalah H. pylori positif dan 31 (51.67\%) negatif. Tidak ada perbedaan signifikan yang ditemukan antara IMT, LP, dan albumin terhadap H. pylori gastritis dengan nilai p masing-masing 0.099, 0.055, dan 0.528. Hemoglobin ditemukan signifikan dengan p 0.009. Kadar rerata resistin pada kelompok H. pylori positif adalah $7.62 \mathrm{ng} / \mathrm{mL}$ sedangkan pada kelompok negatif adalah $3.23 \mathrm{ng} / \mathrm{mL}$, dan signifikan secara statistik $(p<0.001)$. Dijumpai korelasi positif kuat antara kadar resistin dengan IMT dan LP (IMT p 0.01, r 0.577; LP p 0.001, r 0.592).

Simpulan: Kadar resistin pada gastritis H. pylori positiflebih tinggi daripada H. pylori negatif, indeks massa tubuh dan lingkar pinggang memiliki hubungan yang kuat dengan kadar resistin pada pasien dengan gastritis H. pylori positif, hemoglobin lebih rendah pada H. pylori positif daripada negatif.

Kata kunci: resistin, gastritis, Helicobacter pylori, indeks massa tubuh, obesitas

\section{INTRODUCTION}

Gastritis is inflammation of the gastric mucosa, caused by Helicobacter pylori, bile reflux, nonsteroidal anti-inflammatory or allergic respons. ${ }^{1}$ The incidence of gastritis in Southeast Asia around 583,635 of the total population every year. ${ }^{2}$ H.pylori is the most common cause of gastritis. The prevalence of $H$. pylori infection in peptic ulcer patients varies between $90-$ $100 \%$ in Indonesia. ${ }^{3}$

Adipose tissue in obesity have a biological role, not only play a role in triglycerides metabolic processes but also acts as an endocrine gland that secretes various cytokines and peptide hormones which play a role not only in regulating the balance of body weight and energy metabolism, but also in the inflammatory process. Some of these substances are adiponectin, leptin, resistin, interleukin- 6 , tumor necrosis factor- $\alpha$ $(\mathrm{TNF}-\alpha){ }^{4}$ Resistin is thought to have a role in the condition of insulin resistance. ${ }^{5}$

Together with adiponectin, resistin has been a research topic for the past several decades. Hypoadiponectinemia is associated with various diseases, including gastritis. In previous studies it was said that the anti-inflammatory properties of adiponectin have a protective effect against gastrointestinal diseases. In contrast resistin has a proinflammatory effect. ${ }^{6}$ In addition, Samuel et. al showed that subjects who were lean and resistant to insulin might have higher levels of pro-inflammatory markers (MCP-1, IL-6 and resistin) than subjects who were overweight and still insulin sensitive. ${ }^{7}$

There has been no report exploring resistin levels in $H$. pylori gastritis patients, we therefore studied the difference level of resistin between positive and negative $H$. pylori gastritis patients and their relationship with nutritional status (body mass index, waist circumference, hemoglobin, and albumin.

\section{METHOD}

This cross sectional study was conducted at the Endoscopic Unit of H. Adam Malik Hospital and other network hospital in Medan, North Sumatera, after obtaining approval from the Health Research Ethics Commission and related institutions. The time of the study was carried out on May to October 2019.

The inclusion criterias were men and women who are not pregnant aged 18-70 years, diagnosed with gastritis from endoscopic examination results histopathology. The exclusion criterias were patients who received $H$. pylori eradication therapy in the last 6 months or currently on antibiotic therapy which commonly used in eradication therapy, take Proton Pump Inhibitor, H2-receptor antagonist, non-steroid anti inflammation drugs, steroids, alcohol for the past 48 hours, patients with systemic diseases and malignancies, and the subject refused to participate.

Dyspepsia according to Rome III criteria is one or more symptoms: fullness after eating, feeling full quickly, epigastric pain, or burning sensation in the epigastrium that occurs in the last 3 months, with the onset of symptoms occurring at least 6 months before diagnosis.

A $4 \mathrm{~mL}$ blood sample was inserted into the vacutainer tube without anticoagulation. Blood that has been taken is stored at room temperature for 30-45 minutes until the blood clots and then centrifuged at a speed of $3000 \mathrm{rpm}$ for 15 minutes. The serum formed 
was put into 3 serum tubes, each as much as $0.5 \mathrm{~mL}$ for measurement of resistin, hemoglobin, albumin. Store at $-20^{\circ} \mathrm{C}$ (each given identity: name, gender, date and type of serum sample).

BMI is measured by comparing weight (in kilograms) to height (in meters squared). Waist circumference is measured on the abdomen above the umbilicus in centimeters $(\mathrm{cm})$.

All endoscopic examinations using scopes (Olympus, Tokyo, Japan) in the endoscopic unit of H. Adam Malik Hospital. The endoscopic procedure was performed by an experienced endoscope who is the same at each subject examination. Endoscopy was done after the subject has fasted overnight (10-12 hours). Endoscopy was performed to look at the gastric mucosa whether it has edema, erythema (spotted, patchy, linear)/exudate/bleeding/ erosive; and retrieving networks for CLO checks.

To detect $H$. pylori, two biopsy specimens were each collected from the major curvature in the middle of the body and antrum of gastric. Serology (CLO) was performed by a gastroenterohepatologist who did the endoscopy.

This study used univariate analysis by analyzing the frequency distribution of independent and dependent variables, while bivariate analysis uses an independent $\mathrm{T}$ test if the data is normally distributed, and if the data is not normally distributed using the Mann Whitney test. Nutritional status variables would be tested for correlation with resistin levels using Spearman correlation.

\section{RESULTS}

Sixty patients who met the inclusion criteria included in this study. A total of 34 patients (56.7\%) were male and 26 patients $(43.3 \%)$ were female. The average age is 46.5 years. The majority of respondents in the Batak ethnicity were 37 people $(61.7 \%)$. Most of the patients who were respondents in this study were 27 employees (45\%). The highest level of education is high school, 32 people (53.3\%).

The mean BMI of respondents was $23.35 \pm 3.98 \mathrm{~kg} /$ $\mathrm{m}^{2}$. The mean waist circumference was $84.45 \pm 8.24$ $\mathrm{cm}$, the median hemoglobin was 14 (10.4-16) $\mathrm{g} / \mathrm{dL}$, the average albumin was $4.5 \pm 0.57 \mathrm{~g} / \mathrm{dL}$, and the median value resistin was $5.12(2.12-10) \mathrm{ng} / \mathrm{mL}$.

By using the independent T-test, there were no significant differences found between BMI, waist circumference, and albumin in $H$. pylori gastritis with $\mathrm{p}$ values of $0.099,0.055$, and 0.528 , respectively. Statistical analysis of hemoglobin with the Mann Whitney test found a difference between positive and negative $H$. pylori with a p value of 0.009 .
Table 1. Research subjects characteristics $(n=60)$

\begin{tabular}{ll}
\hline Variable & $\mathbf{n ~ ( \% )}$ \\
\hline Gender & $34(56,7)$ \\
Men & $26(43,3)$ \\
Women & $46,5(24-66)$ \\
Age, median (min-max), years old & \\
Ethnic & $37(61,7)$ \\
Batak & $18(30)$ \\
Java & $5(8,3)$ \\
Aceh & \\
Occupation & $27(45)$ \\
Employees & $14(23,3)$ \\
Housewife & $16(26,7)$ \\
Entrepreneur & $3(5)$ \\
Civil servants & \\
Education & $3(5)$ \\
Elementary school & $14(23,3)$ \\
Middle school & $32(53,3)$ \\
High school & $11(18,3)$ \\
University & $23,35 \pm 3,98$ \\
BMl, (mean \pm SD), kg/m2 & $84,45 \pm 8,24$ \\
WC, (mean \pm SD), cm & $14(10,4-16,0)$ \\
Hb, median (min-max), g/dL & $4,5 \pm 0,57$ \\
Albumin, (mean \pm SD), g/dL & $5,12(2,12-10)$ \\
Resistin, median (min-max), ng/mL &
\end{tabular}

BMI: body mass index, WC: waist circumference, Hb: Hemoglobin

Table 2. Relationship characteristics of research subjects based on positive and negative $\boldsymbol{H}$. pylori groups

\begin{tabular}{|c|c|c|c|}
\hline Variable & $\begin{array}{l}\text { H. pylori positive } \\
(\mathrm{n}=29), \mathrm{n}(\%)\end{array}$ & $\begin{array}{c}H . \text { pylori } \\
\text { negative } \\
(\mathrm{n}=31), \mathrm{n}(\%)\end{array}$ & $\mathbf{p}$ \\
\hline \multicolumn{4}{|l|}{ Gender } \\
\hline Men & $17(58,6)$ & $17(54,8)$ & \multirow[t]{2}{*}{$0,768^{a}$} \\
\hline Women & $12(41,4)$ & $14(45,2)$ & \\
\hline $\begin{array}{l}\text { Age, median } \\
\text { (min-max), years } \\
\text { old }\end{array}$ & $49(25-66)$ & $44(24-63)$ & $0,154^{c}$ \\
\hline \multicolumn{4}{|l|}{ Ethnic } \\
\hline Bataknese & $16(55,2)$ & $21(67,7)$ & \multirow[t]{3}{*}{$0,597^{a}$} \\
\hline Javanese & $10(34,5)$ & $8(25,8)$ & \\
\hline Acehnese & $3(10,3)$ & $2(6,5)$ & \\
\hline \multicolumn{4}{|l|}{ Occupation } \\
\hline Employees & $10(34,5)$ & $17(54,8)$ & \multirow[t]{4}{*}{$0,227^{\mathrm{a}}$} \\
\hline Housewife & $7(24,1)$ & $7(22,6)$ & \\
\hline Entrepreneur & $11(37,9)$ & $5(16,1)$ & \\
\hline Civil servants & $1(3,4)$ & $2(6,5)$ & \\
\hline \multicolumn{4}{|l|}{ Education } \\
\hline Elementary & & & \multirow{4}{*}{$0,005^{a}$} \\
\hline $\begin{array}{l}\text { school } \\
\text { Middle school }\end{array}$ & $\begin{array}{l}3(10,3) \\
10(34,5)\end{array}$ & $\begin{array}{l}0 \\
4(12,9)\end{array}$ & \\
\hline High school & $15(51,7)$ & $17(54,8)$ & \\
\hline University & $1(3,4)$ & $10(32,3)$ & \\
\hline $\begin{array}{l}\text { BMI, (mean } \pm \\
\text { SD), } \mathrm{kg} / \mathrm{m} 2\end{array}$ & $24,22 \pm 4,52$ & $22,5 \pm 3,25$ & $0,099^{b}$ \\
\hline $\begin{array}{l}\text { WC, (mean } \pm \\
\text { SD), cm }\end{array}$ & $86,55 \pm 8,67$ & $82,48 \pm 7,43$ & $0,055^{b}$ \\
\hline $\begin{array}{l}\mathrm{Hb} \text {, median (min- } \\
\mathrm{max} \text { ), g/dL }\end{array}$ & $12,5(10,4-16)$ & $14,6(10,4-16)$ & $0,009^{c}$ \\
\hline $\begin{array}{l}\text { Albumin, (mean } \pm \\
\text { SD), } g / d L\end{array}$ & $=4,55 \pm 0,59$ & $4,46 \pm 0,54$ & $0,528^{\mathrm{b}}$ \\
\hline
\end{tabular}

There were significant mean differences $(\mathrm{p}<0,001)$ of resistin levels in patients with positive and negative H. pylori. The mean resistance in the positive $H$. pylori group was higher with an average of $7.62 \mathrm{ng} / \mathrm{mL}$ while in the group with $H$. pylori negative with an average of $3.23 \mathrm{ng} / \mathrm{mL}$.

By using the Spearman correlation test to determine the relationship between resistin and body mass index and waist circumference in group of patients with H. pylori positive, showed there was a strong and 
positive relationship between resistin levels with body mass index and waist circumference and statistically significant (BMI p 0,01, r 0,577, WC p 0,001, r 0,592)

Table 3. Resistin levels based on positive and negative H. pylori groups

\begin{tabular}{llll}
\hline Variable & $\begin{array}{l}\text { H. pylori } \\
\text { positive }\end{array}$ & $\begin{array}{l}\text { H. pylori } \\
\text { negative }\end{array}$ & p \\
\hline $\begin{array}{l}\text { Resistin, median } \\
\text { (min-max), ng/mL }\end{array}$ & $7,62(3,76-10)$ & $3,23(2.12-7,87)$ & $<0,001$ \\
\hline
\end{tabular}

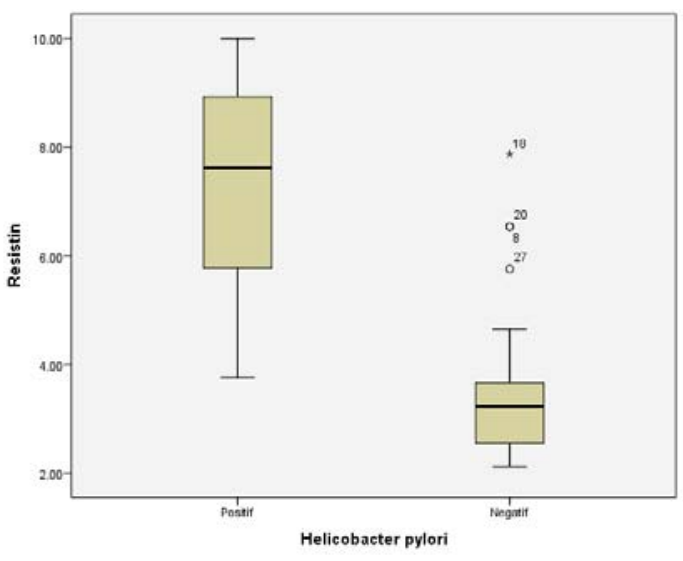

Figure 1. Differences in Resistin Levels between groups of patients with positive and negative $H$. pylori

Table 4. Relationship of BMI, WC, Hb, Albumin to resistin levels in the group with positive $H$. pylori

\begin{tabular}{|c|c|c|}
\hline \multirow{2}{*}{ Variable } & \multicolumn{2}{|c|}{ Resistin } \\
\hline & $p$ & $r$ \\
\hline Body mass index (BMI) & 0,01 & 0,577 \\
\hline Waist circumference (WC) & 0,001 & 0,592 \\
\hline Hemoglobin $(\mathrm{Hb})$ & 0,842 & 0,039 \\
\hline Albumin & 0,543 & 0,118 \\
\hline
\end{tabular}

\section{DISCUSSION}

The average age is 46.5 years in this study but not statistically significant between two groups $(\mathrm{p}=0.154)$. The characteristic baseline data in this study is also based on gender where the results of this study were 34 patients $(56.7 \%)$ were male and 26 patients $(43.3 \%)$ were female. Statistical analysis of sex relations with positive or negative $H$. pylori did not show significant results $(p=0.768)$. This is in accordance with the study of Al-Zubaidi ${ }^{8}$, in obese and non-obese patients with positive $H$. pylori infections, found $65 \%$ were male, but gender was not significantly related to $H$. pylori $(\mathrm{p}=0.200)$.

In terms of socio-economic demographic factors, most of the patients who were respondents in this study were 27 private employees (45\%). The highest level of education is high school, 32 people (53.3\%). However, a statistical analysis of the employment relationship with positive and negative $H$. pylori was found to be insignificant, while a statistical analysis of the educational level with $H$. pylori was found to be significantly different from the results of $p 0.005$ $(\mathrm{p}<0.05)$. Demographic and socioeconomic factors were assessed in a study by Genta et al of 487,587 Americans who underwent endoscopy with a biopsy. ${ }^{9}$ High income levels and higher education are associated with a decrease in the prevalence of $H$. pylori gastritis, as well as intestinal metaplasia and gastric atrophy.

One important factor affecting the upper gastrointestinal tract is BMI which is known to be associated with gastritis. From this study, BMI and WC of positive $H$. pylori group was higher than $H$. pylori negative, however, bivariate analysis found no significant differences (p: 0.099 and 0.055, respectively). In line with the study of Akeel et. al ${ }^{10}$ found a non-significant difference in prevalence among various categories of BMI.

Bivariate analysis of hemoglobin in this study found a difference between positive and negative $H$. pylori $(\mathrm{p}=0.009), \mathrm{Hb}$ was lower in $H$. pylori positive group. In line with Mwafy \& Afana, it shows that the average level of hemoglobin is significantly lower in $H$. pylori infection and $H$. pylori infection seems to cause a decrease in vitamin B12 levels, iron levels and several haematological parameters. ${ }^{11}$ Albumin showed no significant differences between two groups (p: 0.528). In line with research by Rasane et al found that $H$. pylori negative group had lower serum albumin levels $(2.97 \pm 0.96$ vs. $3.86 \pm 0.91 ; \mathrm{p}=0.0001) .{ }^{12}$

To determine the mechanism underlying the relationship between obesity and $H$. pylori gastritis, we examined the serum concentration of resistin in the same subject previously analyzed for the relationship of BMI with $H$. pylori gastritis, and found that the prevalence of $H$. pylori gastritis increased when resistin levels increased, using the Mann Whitney test found a significant mean difference $(p<0.001)$ of resistin levels in patients with positive and negative $H$. pylori gastritis. The mean resistin in the group with $\mathrm{H}$. pylori positive was higher with an average of $7.62 \mathrm{ng} / \mathrm{mL}$ while in the group with $H$. pylori negative with a mean of $3.23 \mathrm{ng} / \mathrm{mL}$.

Higher levels of resistin was found in $H$. pylori gastritis. Although it has not been able to clarify the role of resistin in the pathogenesis of $H$. pylori gastritis in this study, it is suspected that resistin is indeed proinflammatory in gastritis. Previous research examining resistin levels in $H$. pylori infection in humans has not yet been established. 
Resistin regulation in carbohydrate metabolism is thought to be associated with insulin resistance. Resistin is able to regulate the metabolism of insulinstimulated carbohydrates in many insulin target organs. ${ }^{13}$ Since the discovery of resistin, most studies have focused the relationship of resistance to obesity and diabetes.

Resistin has also been involved in inflammatory conditions and has been shown to be secreted in sufficient quantities by mononuclear cells. Its role in inflammation is the induction of expression and release of IL-1b, IL-6, IL-8, IL-12, TNF- $\alpha$, and Tolllike-receptor-2 (TLR-2) through the NF-kB pathway. ${ }^{14}$

Together with adiponectin, resistin has been a research topic for the past several decades. Hypoadiponectinemia is associated with various diseases, including gastritis. In previous studies it was said that the anti-inflammatory properties of adiponectin have a protective effect against gastrointestinal diseases. In contrast resistin has a proinflammatory effect. ${ }^{6}$ In addition, Samuel et al showed that subjects who were lean and resistant to insulin might have higher levels of pro-inflammatory markers (MCP-1, IL-6 and resistin) than subjects who were overweight and still insulin sensitive.?

By using the Spearman correlation test of resistin with BMI in a group of patients with $H$. pylori positive, r 0.577 with $p=0.01$, and with WC r 0.592 with $p$ $=0.001$ was found, meaning that there was a strong relationship between resistin levels with BMI and statistically significant. Hassan and Azim showed that there were statistically significant differences between the levels of resistin in the three groups ( $p<0.001)$, group I: BMI less than 25\%, and hemoglobin levels less than $11 \mathrm{~g} / \mathrm{dL}$, group II: BMI more than $30 \%$ and the hemoglobin level is less than $11 \mathrm{~g} / \mathrm{dL}$, group III: healthy control with BMI less than $25 \% .{ }^{15}$ In group II there was a statistically significant direct correlation between serum resistin levels and BMI. There is a statistically significant inverse correlation between resistin level and hemoglobin level which indicates that an increase in hemoglobin level is associated with a decrease in resistin levels and vice versa.

However, to investigate whether resistin is related to $H$. pylori gastritis independently of body mass index, a multivariate analysis should be undertaken which includes other potential risk factors for gastritis, such as living habits (smoking, food, and drinking alcohol) as well as markers of serum metabolism (cholesterol, triglycerides, glucose, and insulin levels), in addition to body mass index, waist circumference, and resistin.

\section{CONCLUSION}

Resistin levels in gastritis with H. pylori positive are higher than $H$. pylori negative. Body mass index and waist circumference have a strong relationship with resistin levels in patients with positive $H$. pylori gastritis. Hemoglobin is found to be lower in H. pylori positive than negative gastritis.

\section{ACKNOWLEDGEMENTS}

The authors gratefully acknowledge that the present research is supported by Ministry of Research and Technology and Higher Education Republic of Indonesia. The support is under the research grant DRPM, Contract Number 13/UN5.2.3.1/PPM/KPDRPM/2019.

\section{REFERENCES}

1. Burkitt MD, Duckworth CA, Williams JM, Pritchard DM. Helicobacter pylori-induced gastric pathology: Insights from in vivo and ex vivo models. DMM Dis Model Mech 2017;10:89-104.

2. Bidjuni H. Hubungan Stres Dengan Kejadian Gastritis Pada Remaja Kelas Xi Ipa Di Sma Negeri 9 Manado. J Keperawatan 2014;2:X-X.

3. Syam AF, Simadibrata M, Makmun D, Abdullah M, Fauzi A, Renaldi K, et al. National Consensus on Management of Dyspepsia and Helicobacter pylori Infection. Acta Med Indones 2017;49:279-87.

4. Makki K, Froguel P, Wolowczuk I. Adipose Tissue in Obesity-Related Inflammation and Insulin Resistance: Cells, Cytokines, and Chemokines. ISRN Inflamm 2013;2013:1-12.

5. Su KZ, Li YR, Zhang D, Yuan J, Zhang C, Liu Y, et al. Relation of Circulating Resistin to Insulin Resistance in Type 2 Diabetes and Obesity: A Systematic Review and Meta-Analysis. Front Physiol 2019;10:1-10.

6. Yamamoto S, Watabe K, Tsutsui S, Kiso S, Hamasaki T, Kato $\mathrm{M}$, et al. Lower serum level of adiponectin is associated with increased risk of endoscopic erosive gastritis. Dig Dis Sci 2011;56:2354-60.

7. Moscavitch SD, Kang HC, Filho RAC, Mesquita ET, Neto HCCF, Rosa MLG. Comparison of adipokines in a crosssectional study with healthy overweight, insulin-sensitive and healthy lean, insulin-resistant subjects, assisted by a family doctor primary care program. Diabetol Metab Syndr 2016;8:1-8.

8. Al-Zubaidi AM, Alzobydi AH, Alsareii SA, Al-Shahrani A, Alzaman N, Kassim S. Body mass index and Helicobacter pylori among obese and non-obese patients in najran, saudi arabia: A case-control study. Int J Environ Res Public Health 2018;15:1-8.

9. Genta RM, Turner KO, Sonnenberg A. Demographic and socioeconomic influences on Helicobacter pylori gastritis and its pre-neoplastic lesions amongst US residents. Aliment Pharmacol Ther 2017;46:322-30.

10. Akeel M, Elmakki E, Shehata A, Elhafey A, Aboshouk T, Ageely $\mathrm{H}$, et al. Prevalence and factors associated with $H$. pylori infection in Saudi patients with dyspepsia. Electron Physician 2018;10:7279-86. 
11. Mwafy SN, Afana WM. Hematological parameters, serum iron and vitamin B12 levels in hospitalized Palestinian adult patients infected with Helicobacter pylori: a case-control study. Hematol Transfus Cell Ther 2018;40:160-165.

12. Rasane RK, Horn CB, Centeno AA, Fiore NB, Barboza MT, Zhang Q, et al. Are patients with perforated peptic ulcers who are negative for Helicobacter pylori at a greater risk? Surg Infect (Larchmt) 2019;20:444-8.

13. Claire M, Steppan, Shannon T, Bailey, Savitha Bhat, Elizabeth J. Brown, Ronadip R. Banerjee, Christopher M. Wright, Hiralben R. Patel RSA\& MAL. Notice of Clean Up Action. Nature 2001;409:307.

14. Wozniak SE, Gee LL, Wachtel MS, Frezza EE. Adipose tissue: The new endocrine organ? a review article. Dig Dis Sci 2009;54:1847-56.

15. Hassan SM, Azim AMA. International journal of dentistry and oral health serum resistin and its relation to hemoglobin levels in obese patients suffering from iron deficiency anemia. A Clinical Study 2018;4:58-63. 